\title{
PROSES PEREBUSAN KELAPA SAWIT PADA STASIUN STERILIZER (Studi Kasus pada PT. Tri Bakti Sarimas PKS 2 Ibul, Riau)
}

\author{
Lilis Masruroh, dan Hermiza Mardesci * \\ Program Studi Teknologi Pangan, Fakultas Pertanian \\ Universitas Islam Indragiri \\ Jl. Provinsi Parit 1 Tembilahan Hulu - Indragiri Hilir, Riau 29213 \\ *hermizamardesci@unisi.ac.id
}

\begin{abstract}
Abstrak
Proses produksi pengolahan tandan buah segar (TBS) kelapa sawit menjadi minyak sawit/Crude Palm Oil (CPO) melewati beberapa tahap pengolahan. Tahapan pengolahan tersebut dilakukan di beberapa stasiun, diantaranya stasiun penerimaan, stasiun sortasi, stasiun sterilizer, stasiun thresher, stasiun digester dan press, dan stasiun clarifikasi. Salah satu proses yang sangat penting berada pada stasiun sterilizer. Kualitas CPO yang dihasilkan, salah satunya bergantung pada proses perebusan di stasiun sterilizer. Proses perebusan TBS di PT. Tri Bakti Sarimas PKS 2 Ibul menggunakan sistem double peak, dengan tekanan sekitar 2,5 sampai 3 bar. Proses perebusan dilakukan selama 60 sampai 90 menit. Waktu proses yang cukup lama tersebut, akan mematangkan buah sampai ke lapisan bawah.

Kata Kunci : TBS, CPO, Sterilizer, Perebusan, Minyak Sawit
\end{abstract}

Submit: 16 November 2020 * Revisi: 30 November 2020 * Accepted: 27 Jan 2021 * Publish: 10 Mei 2021 


\section{PENDAHULUAN}

Berdasarkan data Statistik Indonesia Tahun 2020, produksi kelapa sawit pada tahun 2019 sebesar 45.859.200 ton, yang 35\%-nya merupakan hasil produksi dari perkebunan rakyat (BPS, 2020). Jumlah perusahaan yang mengolah kelapa sawit di Indonesia cukup banyak. Apalagi di Provinsi Riau yang merupakan salah satu provinsi penghasil sawit di Indonesia. Salah satu perusahaan tersebut adalah PT. Tri Bakti Sarimas PKS 2 Ibul.

Pengolahan kelapa sawit di PT. Tri Bakti Sarimas PKS 2 Ibul melewati beberapa tahap pegolahan, seperti sortasi, perebusan, pembrondolan, pengepresan dan pemurnian minyak. Proses perebusan merupakan salah satu proses yang sangat penting dalam menghasilkan CPO. Menurut Mahyunis, et al. (2015), perebusan yang tidak sempurna pada stasiun sterilizer akan menyebabkan menurunnya efisiensi proses pemecahan biji pada saat pembrondolan di stasiun thresher.

Oleh sebab itu, penelitian ini dilakukan untuk mengetahui proses perebusan TBS pada stasiun sterilizer di PT. Tri Bakti Sarimas PKS 2 Ibul.

\section{METODOLOGI PENELITIAN}

Penelitian dilakukan di PT. Tri Bakti Sarimas PKS 2 Ibul pada bulan Januari sampai Februari 2020. Penelitian dilakukan dengan cara pengamatan dan wawancara langsung dengan karyawan PT. Tri Bakti Sarimas PKS 2 Ibul. Pengamatan dan wawancara dilakukan untuk mengetahui proses perebusan tandan buah segar (TBS) kelapa sawit di stasiun sterilizer pada PT. Tri Bakti Sarimas PKS 2 Ibul.

\section{HASIL DAN PEMBAHASAN}

Sterilizer adalah bejana uap yang digunakan untuk merebus TBS. Untuk menjaga tekanan dalam perebusan agar tidak melebihi tekanan kerja yang dizinkan, maka alat perebus diberi katup pengamanan (safety vave). Perebusan TBS menggunakan media pemanas yang merupakan uap basah sisa pembuangan turbin uap dengan tekanan sekitar 3 $\mathrm{kg} / \mathrm{cm}^{2}$, dan suhu sekitar $145^{\circ} \mathrm{C}$ (Baldani dan Ta'ali, 2020).

Di PT. Tribakti Sarimas PKS 2 Ibul, perebusan TBS menggunakan sterilizer vertical. Menurut Baldani dan Ta'ali (2015), berdasarkan posisinya, mesin perebusan terdiri dari 2, yaitu horizontal dan vertikal. Jika perebusan dilakukan secara vertikal, maka akan mengurangi biaya perawatan pabrik. Hal ini disebabkan karena, perebusan ini tidak menggunakan lori sebagai tempat merebusnya. Jadi, TBS dari loading ramp akan diangkut menggunakan conveyor lalu dimasukkan ke sterlizer. Apabila sterilizer dalam keadaan kosong, maka feeder chute akan memutar menuju sterilizer dan feeder gate akan membuka. Akibatnya TBS masuk ke dalam sehingga sterilizer terisi penuh. Kapasitas sterilizer ini adalah 25 ton dalam 1 bejana. Di perusahaan ini terdapat 4 bejana pada stasiun sterilizer ini. Setelah terisi penuh feeder chute akan kembali menutup dan feeder gate akan menutup secara otomatis.

\section{Mekanisme Perebusan Buah}

Sistem perebusan buah harus sesuai dengan kemampuan boiler memproduksi uap dengan sasaran bahwa tujuan perebusan dapat tercapai. Sistem perebusan yang baik yang dikenal pada pabrik menggunakan single peak, double peak, dan tripple peak. Sistem perebusan ini berfungsi sebagai tindakan fisika. 
Namun, pada saat perebusan juga dapat terjadi proses mekanik, yaitu adanya goncangan yang disebabkan oleh perubahan tekanan yang cepat.

Proses perebusan TBS sebelum dilakukan pengolahan lebih lanjut bertujuan untuk (Parulian, 2007; Sitepu, 2011; Suandi, et al., 2016; Hikmawan dan Angelina, 2019):

1. Menonaktifkan atau merusak enzim, dan menghentikan peragian yang dapat mengakibatkan pembentukan atau kenaikan asam lemak bebas.

TBS yang baru dipanen biasanya masih mengandung enzim lipase yang bertindak sebagai katalisator dalam pembentukan asam lemak bebas. Selain itu, TBS juga mengandung enzim oksidase yang berperan dalam pembentukan peroksida yang kemudian berubah menjadi gugus aldehyde. Jika TBS mengalami luka atau memar, maka aktivitas enzim lipase dan oksidase semakin tinggi. Jika dilakukan pemanasan sampai suhu $>50{ }^{\circ} \mathrm{C}$, maka enzim menjadi tidak aktif lagi. Maka, perebusan dengan suhu tinggi akan menghentikan aktivitas enzim.

2. Membekukan getah dan protein

Pemanasan melaui perebusan di stasiun sterilizer akan dapat membekukan getah yang terdapat pada TBS. Selain itu, suhu yang tinggi pada perebusan dapat membekukan protein.

3. Memudahkan berondolan lepas dari tandan.

Untuk memudahkan pengambilan (ekstraksi) minyak, maka berondolan (buah) sawit harus dipisahkan dari tandannya. Pelepasan berondolan terjadi karena adanya hidrolisa pectin di pangkal buah. Dengan adanya perebusan di stasiun sterilizer, hidrolisa pectin menjadi lebih cepat. Namun hidrolisa pectin pada tangkai, tidak seluruhnya bisa melepaskan berondolan. Oleh sebab itu, proses selanjutnya di stasiun thresher diperlukan untuk perontokan.

4. Melunakkan daging buah agar mudah dilumat dalam digester.

Pemanasan melalui perebusan di stasiun sterilizer akan menyebabkan serat pada kulit buah kelapa sawit menjadi mudah lepas. Jika hal itu terjadi, maka proses selanjutnya di dalam digester dan depericarper/ polishing akan menjadi lebih mudah.

5. Mengurangi kadar air dalam buah sehingga meningkatkan meningkatkan efisiensi pemecahan pada biji sawit (nut).

Proses perebusan di stasiun sterilisasi dapat mengurangi kadar air pada buah dan biji sawit, yaitu dengan cara penguapan. Dengan berkurangnya kadar air, maka efisiensi pemecahan pada biji sawit menjadi meningkat.

6. Mengkondisikan daging buah agar sel minyak dapat terlepas untuk diekstraksi.

Interaksi panas dan proses menurunnya kadar air tersebut, akan menyebabkan minyak sawit adari antara sel bersatu, dan memiliki kekentalan yang rendah. Dengan begitu, proses ekstraksi menjadi lebih mudah.

7. Memudahkan proses pada selanjutnya

Proses perebusan yang terjadi di stasiun sterilizer akan dapat membantu pelepasan serat dan biji. Selain itu, perebusan juga bisa 
membantu proses pelepasan inti dari cangkang. Dengan terlepasnya biji dari serat, kemudian inti dari cangkang, maka proses selanjutnya di stasiun thresher, dan digester akan menjadi lebih mudah.

8. Untuk mencapai tujuan perebusan tersebut, diperlukan tekanan uap 3 bar dengan siklus perebusan 60 sampai 70 menit, dan pada temperatur 120 sampai $130{ }^{\circ} \mathrm{C}$. Sistem perebusan di PT. Tri Bakti Sarimas PKS 2 Ibul menggunakan sistem dua puncak (double peak). Kurva perebusan 2 puncak (double peak) dapat dilihat pada Gambar 1.

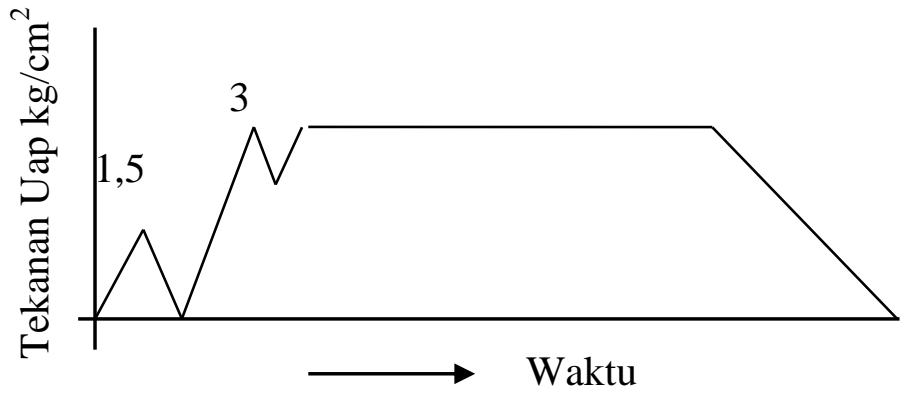

Gambar 1. Kurva Perebusan Double Peak

Proses perebusan double peak adalah proses perebusan yang dilakukan 2 tahap pemasukan uap. Proses pembuangan uap air juga dilakukan dua tahap (Sitepu, 2011). Sistem perebusan double peak di PT. Tri Bakti Sarimas PKS 2 Ibul melewati beberapa tahapan/step sebagai berikut:

1. Step perebusan

- Step pertama berlangsung selama 2 sampai 3 menit.

- Step kedua, steam masuk dengan tekanan 1,5 bar selama 10 menit.

- Step ketiga adalah tahapan pertama untuk buang kondensat sampai tekanan 0 bar.

- Step keempat, steam masuk dengan tekanan 3 bar selama 15 menit.

- Step kelima merupakan proses perebusan selama 30 menit.

- Step keenam adalah amblas kedua atau buang kondensat yang dilakukan selama 5 menit

\section{Langkah kerja sterilizer}

- Pertama-tama top door dibuka.

- Selanjutnya feeder gate dibuka, dan feeder chute diarahkan ke ruang sterilizer.

- Apabila sterilizer telah terisi penuh, maka feeder gate ditutup, dan feeder chute dikembalikan pada posisi home (semula) dan top door ditutup.

- Selanjutnya steam inlet valve dibuka agar steam masuk ke ruang perebusan

- Kemuadian steam outlet water valve ditutup, atau condensate dan exhaust valve ditutup.

- Apabila telah melalui amblas pertama tekanan steam 1,5 bar, dan amblas kedua setelah tekanan steam mencapai 3 bar. Kemudian proses penahanan berlangsung \pm 40 menit, maka dapat dikatakan proses perebusan selesai.

- Setelah perebusan selesai, maka pintu sterilizer dibuka, dan buah 
didorong dengan internal conveyor agar keluar menuju drive conveyor untuk diangkut ke bunch elevator.

Menurut Sitepu (2011), proses perebusan double peak yang merupakan sistem perebusan dua puncak, dimulai dengan cara menaikkan tekanan uap puncak pertama selama 10 menit. Setelah itu dilakukan pembuangan uap. Selanjutnya, tekanan uap puncak kedua juga dinaikkan, dan dilakukan penahanan lebih kurang 45 menit, dan air kondensat dibuang. Hal ini tidak jauh berbeda dengan proses yang terdapat di PT. Tri Bakti Sarimas PKS 2 Ibul.

Proses perebusan tidak boleh terlalu lama atau terlalu singkat. Jika terlalu singkat, maka akan banyak buah yang tidak terpipil. Jika terlalu lama, maka kadar air minyak dalam buah akan menurun dan losses pada air kondensat akan bertambah. Air kondensat dari sterilizer akan mengalir melalui strainer, kemudian pipa utama kondensat (main condensate) setelah condensate valve terbuka.

Dengan adanya tekanan dari steam maka air kondensat akan terdorong bersama steam ke arah cerobong asap. Di cerobong asap, steam akan naik dan keluar ke udara, sedangkan air akan tetap di bagian bawah kemudian mengalir ke condensate pit. Dari kondensat pit, air kondensat akan mengalir ke drain pit, yang merupakan gabungan hasil dari drain berbagai peralatan. Setelah itu, terjadi pengutipan minyak kembali dari drain pit air kondensat akan menuju ke water dilution tank. Buah kelapa sawit yang direbus akan dikeluarkan dari sterilizer menggunakan scrapper conveyor dan digerakkan oleh conveyor drive hingga buah jatuh ke bunch elevator menuju thresher.
Menurut Rahardja dan Sopyan (2012), tingginya persentase oil loss di kondensat adalah sebagai akibat waktu perebusan yang terlalu lama. Jika waktu proses deaerasi kurang optimal, maka persentase oil loses di empty bunch akan meningkat. Jadi, proses perebusan buah merupakan proses yang dapat menentukan losses minimal yang terjadi.

Menurut Hikmawan dan Angelina (2019), proses suhu perebusan di stasiun sterilzer mempengaruhi hasil akhir dari minyak sawit. Jika suhu semakin tinggi, maka proses pemasakan akan semakin cepat. Akibatnya, minyak yang dihasilkan juga lebih banyak. Namun, kandungan air dalam minyak juga cukup tinggi. Hal ini disebabkan oleh uap jenuh yang digunakan mengandung air yang sangat banyak.

Selain suhu atau temperatur, yang mempengaruhi hasil minyak sawit adalah tekanan yang digunakan pada stasiun sterilizer. Tekanan yang terlalu rendah akan menyebabkan menurunnya mutu minyak yang dihasilkan. Hal ini disebabkan oleh uap panas tidak dapat menembus ke dalam buah, sehingga buah sulit lepas dari spikletnya.

Perebusan yang optimal adalah perebusan yang dilakukan pada tekanan uap $2,8 \mathrm{~kg} / \mathrm{cm}^{2}$, dan waktu antara 80 sampai 90 menit (Hikmawan dan Angelina, 2019). Hal ini tidak jauh berbeda dengan proses perebusan di PT. Tri Bakti Sarimas PKS 2 Ibul, dimana tekanan yang digunakan adalah 2,5 sampai 3 bar, sedangkan waktu perebusan adalah 60 sampai 90 menit.

\section{KESIMPULAN DAN SARAN}

\section{Kesimpulan}

Proses perebusan TBS di stasiun sterilizer merupakan tahapan yang penting dalam pengolahan minyak sawit. 
Proses ini menentukan kualitas dan kuantitas minyak sawit yang dihasilkan. Hal yang mempengaruhi hasil tersebut adalah tekanan dan waktu yang digunakan dalam proses perebusan. Proses perebusan di PT. Tri Bakti Sarimas PKS 2 Ibul menggunakan sistem dua puncak atau double peak. Tekanan yang digunakan adalah 2,5 sampai 3 bar, sedangkan waktu perebusan adalah 60 sampai 90 menit. Kondisi ini sudah dianggap optimal dalam proses perebusan.

\section{Saran}

Proses perebusan di stasiun sterilizer hendaknya dipertahankan dalam kondisi optimal. Tekanan yang digunakan hendaknya berada dalam range 2,5 sampai 3 bar, dan waktu perebusan berlangsung tidak kurang dari 60 menit, dan tidak lebih dari 90 menit. Diperlukan ketelitian operator alat untuk mengontrol tekanan dan waktu yang digunakan.

\section{DAFTAR PUSTAKA}

Baldani. A.M., dan Ta'ali. 2020. Perancangan Sistem Kontrol Sterilizer Vertical Kelapa Sawit Berbasis Arduino UNO. Jurnal Teknik Elektro dan Vokasional (JTEV), Vol. 06, No. 02. Hal: 8798.

BPS. 2020. Statistik Indonesia Statistical Yearbook of Indonesia 2020. Jakarta: Badan Pusat Statistik.
Hikmawan, O., dan R. Angelina. 2019.

Pengaruh Variasi Waktu dan Tekanan terhadap Kehilangan Minyak pada Air Kondensat di Unit Sterilizer Pabrik Kelapa Sawit. Jurnal Teknik dan Teknologi. Vol. 14, No. 28. Hal: 33-39.

Mahyunis, A.P.G.L. Gaol, dan Hermanto. 2015. Pengaruh Lama Waktu Perebusan terhadap Sifat Kuat Tekan dan Regangan Biji Kelapa Sawit Varietas Tenera di PTPN II PKS Pagar Marbau. Jurnal Agro Estate, Vol. VI No. 2. Hal: 128-144.

Parulian, V. 2007. Analisa Kebutuhan Uap Sistem Sterilizer pada PKS dengan Lama Perebusan 90 Menit. [Skripsi] Universitas HKBP Nommense Medan.

Rahardja, I.B., dan M. Sopyan. 2012. Efektivitas Proses Pembuangan Udara Melalui Pipa Condensate pada Stasiun Rebusan (Sterilizer) di Pabrik Kelapa Sawit. Jurnal Citra Widya Edukasi (JCWE). Vol. 4 No. 2. Hal: 15-24.

Sitepu, T. 2011. Analisa Kebutuhan Uap pada Sterilizer Pabrik Kelapa Sawit dengan Lama Perebusan 90 Menit. Jurnal Dinamis, Vol. 11 No. 8. Hal: 27-31.

Suandi, A., N.I. Supardi, dan A. Puspawan. 2016. Analisa Pengolahan Kelapa Sawit dengan Kapasitas Olah 30 ton/jam di PT. BIO Nusantara Teknologi. Jurnal Teknosia, Vol II, No. 17. Hal: 1219. 